\title{
Front Matter: Volume 8694
}

, "Front Matter: Volume 8694," Proc. SPIE 8694, Nondestructive Characterization for Composite Materials, Aerospace Engineering, Civil Infrastructure, and Homeland Security 2013, 869401 (24 April 2013); doi: $10.1117 / 12.2029916$

Event: SPIE Smart Structures and Materials + Nondestructive Evaluation and Health Monitoring, 2013, San Diego, California, United States 


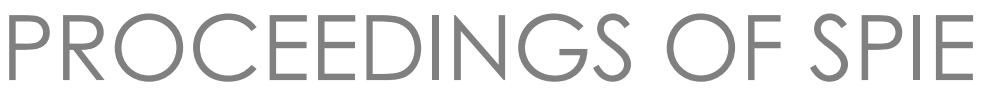

\section{Nondestructive Characterization for Composite Materials, Aerospace Engineering, Civil Infrastructure, and Homeland Security 2013}

Tzu Yang Yu

Andrew L. Gyekenyesi

Peter J. Shull

Aaron A. Diaz

H. Felix Wu

Editors

11-14 March 2013

San Diego, California, United States

Sponsored by

SPIE

Cosponsored by

American Society of Mechanical Engineers (United States)

Cooperating Organizations

Intelligent Materials Forum (Japan)

Jet Propulsion Laboratory (United States)

National Science Foundation (United States)

Published by

SPIE

Volume 8694 
The papers included in this volume were part of the technical conference cited on the cover and title page. Papers were selected and subject to review by the editors and conference program committee. Some conference presentations may not be available for publication. The papers published in these proceedings reflect the work and thoughts of the authors and are published herein as submitted. The publisher is not responsible for the validity of the information or for any outcomes resulting from reliance thereon.

Please use the following format to cite material from this book:

Author(s), "Title of Paper," in Nondestructive Characterization for Composite Materials, Aerospace Engineering, Civil Infrastructure, and Homeland Security 2013, edited by Tzu Yang Yu,

Andrew L. Gyekenyesi, Peter J. Shull, Aaron A. Diaz, H. Felix Wu, Proceedings of SPIE Vol. 8694 (SPIE, Bellingham, WA, 2013) Article CID Number.

ISSN: 0277-786X

ISBN: 9780819494771

Published by

SPIE

P.O. Box 10, Bellingham, Washington 98227-0010 USA

Telephone +1 3606763290 (Pacific Time) · Fax +1 3606471445

SPIE.org

Copyright (@) 2013, Society of Photo-Optical Instrumentation Engineers.

Copying of material in this book for internal or personal use, or for the internal or personal use of specific clients, beyond the fair use provisions granted by the U.S. Copyright Law is authorized by SPIE subject to payment of copying fees. The Transactional Reporting Service base fee for this volume is $\$ 18.00$ per article (or portion thereof), which should be paid directly to the Copyright Clearance Center (CCC), 222 Rosewood Drive, Danvers, MA 01923. Payment may also be made electronically through CCC Online at copyright.com. Other copying for republication, resale, advertising or promotion, or any form of systematic or multiple reproduction of any material in this book is prohibited except with permission in writing from the publisher. The CCC fee code is 0277-786X/13/\$18.00.

Printed in the United States of America.

Publication of record for individual papers is online in the SPIE Digital Library.

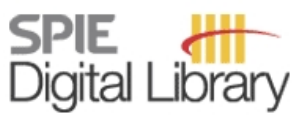

SPIEDigitallibrary.org

Paper Numbering: Proceedings of SPIE follow an e-First publication model, with papers published first online and then in print and on CD-ROM. Papers are published as they are submitted and meet publication criteria. A unique, consistent, permanent citation identifier (CID) number is assigned to each article at the time of the first publication. Utilization of CIDs allows articles to be fully citable as soon as they are published online, and connects the same identifier to all online, print, and electronic versions of the publication. SPIE uses

a six-digit CID article numbering system in which:

- The first four digits correspond to the SPIE volume number.

- The last two digits indicate publication order within the volume using a Base 36 numbering

system employing both numerals and letters. These two-number sets start with 00, 01, 02, 03, 04, $05,06,07,08,09,0 A, 0 B \ldots$. 0Z, followed by 10-1Z, 20-2Z, etc.

The CID Number appears on each page of the manuscript. The complete citation is used on the first page, and an abbreviated version on subsequent pages. Numbers in the index correspond to the last two digits of the six-digit CID Number. 


\section{Contents}

xi Conference Committee

\section{SESSION 1 NDE/SHM FOR COMPOSITES}

869402 The influence of multi-mode failures in composites on the characteristics of elastic waves [8694-1]

L. Zhang, Harbin Institute of Technology (China); D. Ozevin, Univ. of Illinois at Chicago (United States)

869403 Stiffness matrix determination of composite materials using Lamb wave group velocity measurements [8694-2]

O. Putkis, Univ. of Bristol (United Kingdom) and QinetiQ Ltd. (United Kingdom);

A. J. Croxford, Univ. of Bristol (United Kingdom)

869404 Monitoring damage development around stress raisers in carbon/epoxy laminates [8694-3] L. Sripragash, C. Smith, G. Kumaran, M. Sundaresan, North Carolina A\&T State Univ. (United States)

869405 Nondestructive characterization of residual stress within CMOS-based composite microcantilevers [8694-4]

A. A. Rendon-Hernandez, S. Camacho-Leon, S. O. Martinez-Chapa, Tecnológico de Monterrey (Mexico)

\section{SESSION 2 CORROSION AND HEALTH MONITORING OF CIVIL INFRASTRUCTURES}

869406 Theoretical and experimental study on estimation of chloride content in concrete using electromagnetic wave [8694-5]

J. Nojima, H. Ikeda, M. Uchida, T. Mizobuchi, Hosei Univ. (Japan)

869407 Early corrosion monitoring of prestressed concrete piles using acoustic emission [8694-6]

W. Vélez, F. Matta, P. H. Ziehl, Univ. of South Carolina (United States)

869408 Real-world application and validation of vehicle-mounted pavement inspection system [8694-7]

D. M. Vines-Cavanaugh, M. L. Wang, Northeastern Univ. (United States); J. G. McDaniel, Boston Univ. (United States)

$869409 \quad$ Evaluating road surface conditions using tire generated noise [8694-8]

Y. Zhao, Northeastern Univ. (United States); H. F. Wu, Univ. of North Texas (United States);

J. G. McDaniel, Boston Univ. (United States); M. L. Wang, Northeastern Univ. (United States) 
8694 OA Enhanced polymer nanocomposites for condition assessment of wind turbine blades [8694-9]

H. Saleem, M. Thunga, lowa State Univ. (United States); M. Kollosche, Univ. Potsdam

(Germany); M. Kessler, S. Laflamme, lowa State Univ. (United States)

$8694 \mathrm{OB}$ Structural condition assessment of offshore wind turbine monopile foundations using vibration monitoring data [8694-10]

H. C. Gomez, T. Gur, D. Dolan, MMI Engineering Ltd. (United States)

8694 OC Two layer structure for reinforcing pothole repair [8694-1 1]

W. Yuan, K.-Y. Yuan, L. Zou, J.-M. Yang, J.-W. Ju, W. Kao, L. Carlson, Univ. of California, Los Angeles (United States)

\section{SESSION 3 RADAR/MICROWAVE NDE}

8694 ol Wideband subsurface radar for bridge structural health monitoring and nondestructive evaluation [8694-17]

T. Yu, C.-F. Su, Univ. of Massachusetts Lowell (United States); C.-P. Lai, LR Technologies, Inc.

(United States); H. F. Wu, Univ. of North Texas (United States)

8694 OL Preliminary study of matching pursuit for extracting GPR rebar reflections [8694-20]

X. Wei, Y. Zhang, Georgia Institute of Technology (United States); H. F. Wu, Univ. of North Texas (United States)

\section{SESSION 4 FIBER OPTIC SENSORS IN NDE/SHM}

8694 OM Monitoring of out-of-autoclave BMI composites using fiber optic sensors [8694-21] S. Anandan, S. Nagarajan, A. Kaur, K. Chandrashekhara, H. Xiao, Missouri Univ. of Science and Technology (United States)

8694 ON High dynamic range high sensitivity FBG interrogation [8694-22]

N. Stan, D. Bailey, S. Chadderdon, R. H. Selfridge, S. M. Schultz, Brigham Young Univ. (United States); S. Webb, K. J. Peters, M. Zikry, North Carolina State Univ. (United States)

869400 Fiber optic monitoring of a SCARC specimens with crack location prediction [8694-23] B. Smith, S. Chen, Univ. of North Carolina at Charlotte (United States); B. Shi, G. Wei, Nanjing Univ. (China); Z. Bian, China Univ. of Mining and Technology (China)

8694 OP Nondestructive characterization for PDMS thin films using a miniature fiber optic photoacoustic probe [8694-24]

X. Zou, N. Wu, Y. Tian, X. Wang, Univ. of Massachusetts Lowell (United States)

$86940 Q \quad$ Fiber optic photoacoustic ultrasound generator based on gold nanocomposite [8694-25]

N. Wu, Y. Tian, X. Zou, X. Wang, Univ. of Massachusetts Lowell (United States) 
8694 OR Performance evaluation of a combined neutron and x-ray digital imaging system [8694-26] V. Sinha, A. Srivastava, H. K. Lee, X. Liu, Missouri Univ. of Science and Technology (United States)

8694 OS The analysis of air voids in concrete specimen using x-ray computed tomography [8694-27]

Y.-M. Su, N. Hossiney, M. Tia, Univ. of Florida (United States)

\section{SESSION 6 VIBRATION-BASED SHM/NDE I}

8694 OT Acoustic emission signatures of damage modes in structural materials [8694-28]

D. G. Aggelis, Vrije Univ. Brussel (Belgium); A. C. Mpalaskas, T. E. Matikas, Univ. of Ioannina (Greece); D. Van Hemelrijck, Vrije Univ. Brussel (Belgium)

8694 OU Monitoring damage growth in carbon/epoxy composite panels [8694-30]

T. Whitlow, K. Asamene, North Carolina A\&T State Univ. (United States); L. Hudson, A. Parker, NASA Dryden Flight Research Ctr. (United States); M. Sundaresan, North Carolina A\&T State Univ. (United States)

8694 OV Monitoring friction related surface degradation using acoustic emission technique [8694-31]

B. Mills-Dadson, A. I. Islam, K. Asamene, M. Sundaresan, North Carolina A\&T State Univ. (United States)

8694 OW One dimensional predictive model of interfacial stiffness in FRP-bonded concrete system using acoustic-laser technique [8694-32]

D. Lau, City Univ. of Hong Kong (Hong Kong, China)

8694 OX Acoustic emission monitoring and fatigue prediction of steel bridge components [8694-33] J. Yu, P. Ziehl, J. Caicedo, F. Matta, Univ. of South Carolina (United States)

\section{SESSION 7 NDE/SHM FOR AEROSPACE MATERIALS}

$8694 \mathrm{OZ}$ Detection of fretting damage in aerospace materials by thermoelectric means [8694-56]

H. Carreon, Univ. Michoacana de San Nicolás de Hidalgo (Mexico)

869410 Electromechanical impedance for SHM of aircraft bolted joints [8694-57]

V. Pavelko, Riga Technical Univ. (Latvia)

869411 Design modification of cyclically periodic structure using Gaussian process [8694-58]

K. Zhou, J. Tang, Univ. of Connecticut (United States) 
869412 Output-only structural system identification method with a new two-stage Kalman filter and incomplete measurement [8694-59]

Y. Ding, B. Y. Zhao, B. Wu, Harbin Institute of Technology (China)

869414 Damage investigation of single-edge notched beam tests with concrete specimens using acoustic emission techniques [8694-101]

Q. Dai, Michigan Technological Univ. (United States); K. Ng, IET Inc. (United States)

\section{SESSION 9 SHM/NDE FOR BRIDGES}

869418 In-situ health monitoring on steel bridges with dual mode piezoelectric sensors [8694-38]

L. Yu, Univ. of South Carolina (United States); H. F. Wu, Univ. of North Texas (United States);

V. Giurgiutiu, P. Ziehl, Univ. of South Carolina (United States)

869419 Cyber-infrastructure design and implementation for structural health monitoring [8694-39] G. W. van der Linden, A. Emami-Naeini, SC Solutions Inc. (United States); Y. Zhang, J. P. Lynch, Univ. of Michigan (United States)

8694 1A An integrated monitor and warning system for the Jeremiah Morrow Bridge [8694-40] M. Norouzi, A. Adediji, V. Hunt, A. Helmicki, Univ. of Cincinnati (United States)

\section{SESSION 10 MODELING AND SIMULATION IN NDE/SHM}

$8694 \mathrm{lE} \quad$ Finite element model updating of a RC building considering seismic response trends [8694-61]

F. Butt, Univ. of Auckland (New Zealand) and Univ. of Engineering and Technology (Pakistan); P. Omenzetter, Univ. of Aberdeen (New Zealand)

$8694 \mathrm{IF}$ The selection of spectral element polynomial orders for high frequency numerical wave propagation [8694-62]

Z. Heidary, D. Ozevin, Univ. of Illinois at Chicago (United States)

8694 1G Numerical predictions of viscoelastic properties and dynamic moduli of innovative pothole patching materials [8694-63]

K. Y. Yuan, W. Yuan, J. W. Ju, J. M. Yang, W. Kao, L. Carlson, Univ. of California, Los Angeles (United States)

$86941 \mathrm{H} \quad$ Numerical study of structural change estimation in a rotor system based on changes in resonance and antiresonance frequencies [8694-64]

A. C. Wroblewski, Cleveland State Univ. (United States) 
$86941 \mathrm{~J}$ Design and simulation of a slotted patch antenna sensor for wireless strain sensing [8694-66]

X. Yi, C. Cho, B. Cook, Y. Wang, M. M. Tentzeris, Georgia Institute of Technology (United

States); R. T. Leon, Virginia Polytechnic Institute and State Univ. (United States)

$86941 \mathrm{~K}$ Optimal sensor placement for structural health monitoring: a comparative study between the control engineering and civil engineering approaches [8694-67]

G. Movva, Y. Wan, S. Fu, H. F. Wu, Univ. of North Texas (United States)

$8694 \mathrm{lL}$ Implementation of a compressive sampling scheme for wireless sensors to achieve energy efficiency in a structural health monitoring system [8694-68]

S. M. O'Connor, J. P. Lynch, A. C. Gilbert, Univ. of Michigan (United States)

$86941 \mathrm{M} \quad$ Full-scale testing of civil structures using wireless sensing technologies [8694-69]

Z. Huang, H. F. Wu, Univ. of North Texas (United States)

$86941 \mathrm{~N} \quad$ Experimental case studies on wireless and wired sensors [8694-70]

K. Dai, Y. Huang, Tongji Univ. (China); Z. Huang, Univ. of North Texas (United States);

G. Zong, W. Shi, Tongji Univ. (China)

869410 Multilayer transfer matrix characterization of complex materials with scanning acoustic microscopy [8694-44]

J. N. Kim, R. Tutwiler, The Pennsylvania State Univ. (United States); D. R. Kwak, I. Park, Seoul National Univ. of Technology (Korea, Republic of); C. Miyasaka, The Pennsylvania State Univ. (United States)

8694 IP Integration of computational model and SEM imaging technology to investigate internal frost damage in cementitious materials [8694-45]

Q. Dai, K. Ng, Michigan Technological Univ. (United States)

8694 IR Designing 2D arrays for SHM of planar structures: a review [8694-47]

T. Stepinski, AGH Univ. of Science and Technology (Poland) and Uppsala Univ. (Sweden);

L. Ambrozinski, T. Uhl, AGH Univ. of Science and Technology (Poland)

8694 is An ultrasonic wave-front with propagation direction dependent frequency [8694-48] S. B. Palmer, S. Hill, G. Rowlands, S. Dixon, The Univ. of Warwick (United Kingdom)

$86941 \mathrm{U}$ Overall evaluation light-weight composite pressure vessel with alloy liner by acoustic emission and Bragg grating [8694-50]

J. Zhao, X. He, R. Wang, W. Liu, Harbin Institute of Technology (China) 
$86941 \mathrm{~V}$ Structural noise reduction in frequency modulated thermal wave imaging of carbon fibre composite materials [8694-71]

K. Chatterjee, S. Tuli, Indian Institute of Technology Delhi (India)

$86941 \mathrm{X}$ The effect of creep on magnetic domain structure of heat resistant steels [8694-85]

S. Z. Zhang, S. T. Tu, East China Univ. of Science and Technology (China)

\section{SESSION 14 ELECTRICAL AND MAGNETIC NDE}

$86941 Y \quad$ Imaging and detection of cracks in metallic structures with eddy current sensors [8694-74]

D. Placko, T. Bore, A. Rivollet, Ecole Normale Supérieure de Cachan (France)

869412 Multiple defect interpretation based on Gaussian processes for MFL technology [8694-75] B. Wijerathna, T. Vidal-Calleja, S. Kodagoda, Q. Zhang, J. Valls Miro, Univ. of Technology, Sydney (Australia)

869420 A novel methodology to determine needle position for DC potential difference method to evaluate hardening depth from surface [8694-76]

A. Sasamoto, T. Suzuki, National Institute of Advanced Industrial Science and Technology (Japan); M. Iwata, N. Ike, T. Kaneda, EMIC (Japan)

\section{SESSION $15 \quad$ REMOTE SENSING TECHNOLOGIES}

869423 LiDAR scan and smart piezo layer combined damage detection [8694-53]

S. Chen, The Univ. of North Carolina at Charlotte (United States); H. Chung, Acellent Technology (United States); Y. Park, The Univ. of North Carolina at Charlotte (United States)

869424 Bolted connection modeling and validation through laser-aided testing [8694-54]

K. Dai, Tongji Univ. (China) and Chongqing Univ. (China); C. Gong, Tongji Univ. (China);

B. Smith, The Univ. of North Carolina at Charlotte (United States)

\section{SESSION $16 \quad$ NDE FOR NUCLEAR FACILITIES}

869426 Research and development roadmaps for nondestructive evaluation of cables, concrete, reactor pressure vessels, and piping fatigue [8694-77]

D. Clayton, Oak Ridge National Lab. (United States); S. Bakhatiari, Argonne National Lab. (United States); C. Smith, Oak Ridge National Lab. (United States); K. Simmons,

P. Ramuhalli, J. Coble, D. Brenchley, R. Meyer, Pacific Northwest National Lab. (United States)

869428 High-temperature $\left(>1000^{\circ} \mathrm{C}\right)$ acoustic emission sensor [8694-79]

J. A. Johnson, K. Kim, North Carolina State Univ. (United States); S. Zhang, The Pennsylvania State Univ. (United States); D. Wu, North Carolina State Univ. (United States) and Beijing Jiaotong Univ. (China); X. Jiang, North Carolina State Univ. (United States) 
POSTER SESSION

869429 Nondestructive testing in an automated process chain for mass manufacturing of fiberreinforced thermoplastic components [8694-80]

M. Kalms, S. Hellmers, C. v. Kopylow, R. B. Bergmann, Bremer Institut für angewandte Strahltechnik GmbH (Germany)

8694 2A Agent based damaged detection in composite laminates [8694-81]

M. Y. Ali, K. Shankar, The Univ. of New South Wales (Australia)

8694 2B Damage assessment of hydrokinetic composite turbine blades [8694-82]

S. E. Watkins, K. E. Robison, J. R. Nicholas, G. A. Taylor, K. Chandrashekhara, J. L. Rovey, Missouri Univ. of Science and Technology (United States)

8694 2E Fiber optic ultrasound generator using periodic gold nanopattern fabricated by focused ion beam $[8694-86]$

Y. Tian, N. Wu, X. Zou, X. Wang, Univ. of Massachusetts Lowell (United States)

Author Index 
Proc. of SPIE Vol. 8694 869401-10

Downloaded From: https://www.spiedigitallibrary.org/conference-proceedings-of-spie on 25 Apr 2023 Terms of Use: https://www.spiedigitallibrary.org/terms-of-use 


\title{
Conference Committee
}

\author{
Symposium Chairs
}

Norbert G. Meyendorf, Fraunhofer-Institut für Zerstörungsfreie Prüfverfahren (Germany) and University of Dayton (United States)

Norman M. Wereley, University of Maryland, College Park

(United States)

\section{Symposium Cochairs}

Victor Giurgiutiu, University of South Carolina (United States)

Christopher S. Lynch, University of California, Los Angeles

(United States)

Conference Chair

Tzu Yang Yu, University of Massachusetts Lowell (United States)

Conference CoChairs

Andrew L. Gyekenyesi, NASA Glenn Research Center (United States) Peter J. Shull, The Pennsylvania State University (United States)

Aaron A. Diaz, Pacific Northwest National Laboratory (United States) H. Felix Wu, University of North Texas (United States)

Conference Program Committee

A. Emin Aktan, Drexel University (United States)

Sreenivas Alampalli, New York State Department of Transportation (United States)

Farhad Ansari, University of Illinois at Chicago (United States)

Perumalsamy N. Balaguru, Rutgers, The State University of New Jersey (United States)

Radu Barsan, Redfern Integrated Optics, Inc. (United States)

Shawn J. Beard, Acellent Technologies, Inc. (United States)

Aditi Chattopadhyay, Arizona State University (United States)

Genda Chen, Missouri University of Science and Technology (United States)

Shen-En Chen, The University of North Carolina at Charlotte (United States)

Maria Q. Feng, Columbia University (United States)

Masoud Ghandehari, Polytechnic Institute of New York University (United States)

Hamid Ghasemi, Federal Highway Administration (United States) 
Valery F. Godinez-Azcuaga, MISTRAS Group, Inc. (United States)

Nenad Gucunski, Rutgers, The State University of New Jersey

(United States)

Dryver R. Huston, The University of Vermont (United States)

Frank Jalinoos, Federal Highway Administration (United States)

Xiaoning Jiang, North Carolina State University (United States)

Simon Laflamme, lowa State University (United States)

Jerome Peter Lynch, University of Michigan (United States)

Theodoros E. Matikas, University of loannina (Greece)

W. Allen Marr, Geocomp Corporation (United States)

Paul Mlakar, U.S. Army Engineer Research and Development Center (United States)

Franklin L. Moon, Drexel University (United States)

Amir A. Mosavi, SC Solutions, Inc. (United States)

Piotr Omenzetter, The University of Auckland (New Zealand)

Pradeep Ramuhalli, Pacific Northwest National Laboratory

(United States)

Akira Sasamoto, National Institute of Advanced Industrial Science and Technology (Japan)

Masanobu Shinozuka, University of California, Irvine (United States)

Kurt Silvers, Pacific Northwest National Laboratory (United States)

Caesar Singh, U.S. Department of Transportation (United States)

Bernhard R. Tittmann, The Pennsylvania State University (United States)

Dietmar W. Vogel, Fraunhofer-Institut für Zuverlässigkeit und Mikrointegration (Germany)

Yan Wan, University of North Texas (United States)

Ming Wang, Northeastern University (United States)

Yang Wang, Georgia Institute of Technology (United States)

Sharon L. Wood, The University of Texas at Austin (United States)

Lingyu Yu, University of South Carolina (United States)

Xiong Yu, Case Western Reserve University (United States)

Fuh-Gwo Yuan, North Carolina State University (United States)

Ying Zhang, Georgia Institute of Technology (United States)

Jinying Zhu, The University of Texas at Austin (United States)

Mourad Zeghal, Rensselaer Polytechnic Institute (United States)

Paul H. Ziehl, University of South Carolina (United States)

\section{Session Chairs}

1 NDE/SHM for Composites

Xiaoning Jiang, North Carolina State University (United States)

Yang Wang, Georgia Institute of Technology (United States)

Simon Laflamme, lowa State University (United States)

Tzu Yang Yu, University of Massachusetts Lowell (United States) 
2 Corrosion and Health Monitoring of Civil Infrastructures

Ming L. Wang, Northeastern University (United States)

Ying Zhang, Georgia Institute of Technology (United States)

Andrew L. Gyekenyesi, NASA Glenn Research Center (United States)

3 Radar/Microwave NDE

Nenad Gucunski, Rutgers, The State University of New Jersey

(United States)

Tzu-Yang Yu, University of Massachusetts Lowell (United States)

Seong-Noon Kee, Rutgers, The State University of New Jersey (United States)

4 Fiber Optic Sensors in NDE/SHM

Farhad Ansari, University of Illinois at Chicago (United States)

Xingwei Wang, University of Massachusetts Lowell (United States)

Didem Ozevin, University of Illinois at Chicago (United States)

5 Radioactive NDE

Tian Xia, The University of Vermont (United States)

Haifeng Zhang, University of North Texas (United States)

6 Vibration-Based SHM/NDE I

Paul H. Ziehl, University of South Carolina (United States)

Lingyu Yu, University of South Carolina (United States)

7 NDE/SHM for Aerospace Materials

Andrew L. Gyekenyesi, NASA Glenn Research Center (United States)

Xingwei Wang, University of Massachusetts Lowell (United States)

8 Damage Detection Algorithms

Akira Sasamoto, National Institute of Advanced Industrial Science and Technology (Japan)

Didem Ozevin, University of Illinois at Chicago (United States)

9 SHM/NDE for Bridges

Ming L. Wang, Northeastern University (United States)

Genda Chen, Missouri University of Science and Technology (United States)

10 Modeling and Simulation in NDE/SHM

Piotr Omenzetter, The University of Auckland (New Zealand)

Haifeng Zhang, University of North Texas (United States)

11 Wireless SHM

Jerome Peter Lynch, University of Michigan (United States)

Yan Wan, University of North Texas (United States) 
12 Vibration-Based SHM/NDE II

Theodoros E. Matikas, University of loannina (Greece)

Yan Wan, University of North Texas (United States)

13 Thermal NDE

Zhenhua Huang, University of North Texas (United States)

Xiaoning Jiang, North Carolina State University (United States)

14 Electrical and Magnetic NDE

Akira Sasamoto, National Institute of Advanced Industrial Science and Technology (Japan)

Didem Ozevin, University of Illinois at Chicago (United States)

15 Remote Sensing Technologies

Dryver R. Huston, The University of Vermont (United States)

Shen-En Chen, The University of North Carolina at Charlotte (United States)

16 NDE for Nuclear Facilities

Lingyu Yu, University of South Carolina (United States)

Dwight A Clayton, Oak Ridge National Laboratory (United States) 